\title{
FACTORS ASSOCIATED WITH ADHERENCE TO TAKE IRON TABLET AMONG PREGNANT WOMEN IN EMPAT LAWANG DISTRICT, SOUTH SUMATERA
}

\author{
Violita Siska Mutiara'), Dwi Putri Sulistya Ningsih²), Mika Oktarina1) \\ ${ }^{1}$ Diploma Program in Midwifery, School of Health and Sciences \\ Tri Mandiri Sakti, Bengkulu \\ 2)Public Health Program, School of Health and Sciences \\ Tri Mandiri Sakti, Bengkulu
}

\begin{abstract}
Background: Provision of iron in pregnant women is one of the requirements of antenatal care in pregnant women in Indonesia. Iron supplements are particularly important for pregnant women who have anemia.During pregnancy, iron deficiency anemia is a specific risk factor associated with negative maternal and perinatal outcomes. In women who have normal blood values, taking iron supplements as a precautionary measure probably does not have any health benefits. They can get enough iron in their diet. Many countries have iron supplementation (IS) programs-as recommended by the World Health Organization-during pregnancy. Pregnant women with anemia are recommended to take a total of 90 iron tablets during pregnancy. This study aimed to determine factors associated with adherence to take irontablet among pregnant women in EmpatLawang District, South Sumatera.

Subjects and Method: This was a cross-sectional study conducted in Talang Padang community health center, Empat Lawang, South Sumatera, from August to November 2017. A sample of 41 pregnant women of last trimester was selected for this study. The dependent variable was adherence to take the iron tablet. The independent variables were knowledge about antenatal care, side effect, and husband support. The data were collected by questionnaire. The data were analyzed by Chi-Square.

Results: Adherence to take the iron tablet increased with good knowledge (OR= 3.78; $95 \% \mathrm{CI}=1.56$ to $9.13 ; \mathrm{p}=0.002)$, absence of side effect $(\mathrm{OR}=2.57 ; 95 \% \mathrm{CI}=$ 1.09 to $6.13 ; \mathrm{p}=0.032)$, and strong husband support $(\mathrm{OR}=2.20 ; 95 \% \mathrm{CI}=1.03$ to $4.71 ; \mathrm{p}=0.042)$.

Conclusion: Adherence to take the iron tablet increases with good knowledge, absence of side effect, and strong husband support.
\end{abstract}

Keywords: iron tablet, adherence, knowledge, side effect, husband support

\section{Correspodence:}

Violita Siska Mutiara. Diploma Program in Midwifery, School of Health and Sciences Tri Mandiri Sakti. Jl. Hibrida Raya No.3 Sidomulyo, Bengkulu 38229.

Email: violitasiskamutiara@gmail.com. Mobile: 081173600o/o8117301234. 